\title{
Effect of root and leaf applications of soluble silicon on blast development in rice
}

\author{
Isaias Severino Cacique ( $\left.{ }^{1}\right)$; Gisele Pereira Domiciano ('); Wiler Ribas Moreira ( $\left.{ }^{1}\right)$; \\ Fabrício Ávila Rodrigues ( $\left.{ }^{(*)}\right)$; Maria Fernanda Antunes Cruz ('); \\ Núria Sierras Serra ( $\left.{ }^{2}\right)$; Ana Botta Català $\left({ }^{2}\right)$ \\ (1) Viçosa Federal University (UFV), Department of Plant Pathology, Laboratory of Host-Parasite Interaction, \\ 36570-000 Viçosa (MG), Brazil. \\ (2) Biolberica, S.A., Research Department, Plant Physiology Division, Palafolls, 08389 Barcelona, Spain. \\ $\left({ }^{*}\right)$ Corresponding author: fabricio@ufv.br
}

Received: May 7, 2013; Accepted: August 18, 2013

\begin{abstract}
Blast, caused by Pyricularia oryzae, is the most important fungal disease of rice worldwide. This study aimed to compare root and foliar supply of soluble silicon (Si) on rice resistance to blast. The application of soluble Si to the roots increased Si concentration in leaf tissues as compare to plants grown in soil amended with calcium silicate. There was no increase in leaf Si concentration after soluble Si spray, regardless if the leaves were washed or not before analysis. X-ray microanalysis revealed that Si deposition was very similar on the leaf epidermis of plants sprayed with soluble Si, root amended with soluble Si or grown in soil amended with calcium silicate. The lesion size, the number of lesions per $\mathrm{cm}^{2}$ of leaf and the area under blast progress curve were reduced for rice plants grown in soil that received the application of soluble Si or was amended with calcium silicate. The results of this study showed that the supply of soluble Si to the roots or its spray onto to the rice leaves can decrease blast symptoms.
\end{abstract}

Key words: Pyricularia oryzae, foliar disease, mineral nutrition.

\section{Efeito da aplicação radicular e foliar de silício solúvel sobre o desenvolvimento da brusone em arroz}

\section{Resumo}

A brusone, causada por Pyricularia oryzae, é a doença fúngica mais importante do arroz no mundo. O objetivo deste estudo foi comparar o suprimento radicular e foliar de silício solúvel (Si) na resistência do arroz à brusone. A aplicação de Si solúvel para as raízes das plantas de arroz aumentou a concentração de Si nos tecidos foliares quando comparados aos de plantas cultivadas em solo suprido com silicato de cálcio. Não houve aumento na concentração foliar de Si após a aplicação de Si solúvel, independentemente de as folhas terem sido lavadas ou não antes da análise. Foi demonstrado por microanálise de raios-X que a deposição de Si foi muito semelhante na epiderme de plantas pulverizadas com Si solúvel, com raiz supridas com Si solúvel ou cultivadas em solo com silicato de cálcio. O tamanho da lesão, o número de lesões por $\mathrm{cm}^{2}$ de folha e a área abaixo da curva de progresso da brusone foram reduzidos em plantas cultivadas em solos que receberam a aplicação de Si solúvel ou foram supridas com silicato de cálcio. Os resultados deste estudo demonstram que o fornecimento de Si solúvel às raízes ou a sua pulverização sobre as folhas de arroz podem diminuir os sintomas da brusone.

Palavras-chave: Pyricularia oryzae, doença foliar, nutrição mineral.

\section{INTRODUCTION}

Rice blast, caused by Pyricularia oryzae (Cooke) Sacc.) (teleomorph Magnaporthe oryzae (T.T. Hebert) Yaegashi \& Udagawa) Barr is the most important fungal disease of rice (Oryza sativa L.) and causes significant yield losses worldwide (Ou, 1985; Sкамnioti et al., 2009). The application of silicon $(\mathrm{Si})$ to rice fields to control blast is an alternative, especially when rice is grown in soils with low Si availability (DATNOFF et al., 1997; SeEBold et al., 2000). The Si uptake by rice is about twice that of nitrogen
(Savant et al., 1997). A thick layer of silica beneath the cuticle of rice leaves and sheaths (Yoshida et al., 1962) can impede $P$. oryzae penetration and then decrease the number of lesions on the leaf blades (SEEBOLD et al., 2001). In addition, the soluble $\mathrm{Si}$ in plant tissue may somehow be associated with an increase in rice resistance to blast through the production of phenolic-like compounds, diterpenoid phytoalexins and the activation of some PR-genes (Rodrigues et al., 2003; 2004; 2005).

Slags, potassium silicate and sodium silicate, the major Si sources, are applied either to soil, soil-less media or 
hydroponic system to increase the accumulation of this element in plant shoots and enhance host resistance against pathogens attack (BÉLANGER et al., 1995; DATNOFF et al., 2007; Rodrigues et al., 2001). Some studies have determined that leaf application of potassium silicate controlled powdery mildew on leaves of cucumber, grape, muskmelon and zucchini squash (Bowen et al., 1992; Menzies et al., 1992). The root application of $\mathrm{Si}$ was efficient in reducing powdery mildew severity in cucumber and enhancing the activities of peroxidases, polyphenoloxidases and chitinases (LiANG et al., 2005). Leaf application of Si also gave a satisfactory disease control, probably through a physical barrier due to $\mathrm{Si}$ deposition on leaf surfaces or an osmotic effect of the silicate applied. However, leaf application was not able to enhance the activity of enzymes involved in host defense (Liang et al., 2005). The foliar spray of different Si-based formulations was less effective in reducing powdery mildew on wheat plants in comparison to the root application of these formulations (GUÉvel et al., 2007).

Despite the potential of $\mathrm{Si}$ as an alternative strategy to manage blast, the feasibility of $\mathrm{Si}$ to control this disease through leaf application is, to the best of our knowledge, unknown. Therefore, the objective of this study was to investigate the effects of root and leaf Si applications on the deposition of this element on rice leaf tissues and, consequently, on rice blast progress.

\section{MATERIAL AND METHODS}

\section{Soil material, plant growth and application of the treatments}

The soil type used in this experiment was a Si-deficient typical Acrustox red yellow latosol collected at the 'Triângulo Mineiro' savanna area with $530 \mathrm{~g} \mathrm{~kg}^{-1}$ of clay; $\mathrm{pH}$ in $\mathrm{KCl}=4.8 ; \mathrm{P}$ (Mehlich-1) $=0.5 \mathrm{mg} \mathrm{dm}^{-3}$; $\mathrm{K}$ (Mehlich-1) $=13 \mathrm{mg} \mathrm{dm}{ }^{-3} ; \mathrm{Al}^{3+}, \mathrm{Ca}^{2+}, \mathrm{Mg}^{2+}, \mathrm{H}+\mathrm{Al}^{3+}=0.1$, $0.0,0.0$, and $3.8 \mathrm{cmol} \mathrm{dm}_{\mathrm{c}}^{-3}$, respectively; base saturation $=2 \%$ and organic matter $=2.3 \mathrm{dag} \mathrm{kg}^{-1}$. The concentration of available $\mathrm{Si}$ (extraction in $\mathrm{CaCl}_{2}$ ) was $11.8 \mathrm{mg} \mathrm{dm}^{-3}$, which can be considered very low and adequate for an experiment aiming to test the efficiency of any product containing $\mathrm{Si}$. Each plastic pot was filled with $2 \mathrm{~kg}$ of air-dried, sieved $(5 \mathrm{~mm})$ soil. Calcium silicate, used as the Si source (Harsco Minerais, Timóteo, Minas Gerais, Brazil), was composed of $10.5 \% \mathrm{Si}, 25 \% \mathrm{Ca}$ and $6 \% \mathrm{Mg}$. Calcium silicate was incorporated into each pot at the rate of $1.4 \mathrm{~g} \mathrm{~kg}^{-1}$ of soil. Calcium carbonate $(40 \% \mathrm{Ca}$, Sigma-Aldrich, São Paulo, Brazil) was at the rate of $0.95 \mathrm{~g} \mathrm{~kg}^{-1}$ of soil to equilibrate the amount of $\mathrm{Ca}$ in this treatment with the amount present in pots that received $1.4 \mathrm{~g}$ of calcium silicate. Pots receiving calcium carbonate also received 0.39 of magnesium carbonate
(24\% Mg, Sigma-Aldrich, São Paulo, Brazil) per kg of soil. Soil in each pot was incubated for 60 days with humidity around $65 \%$ before sowing five rice seeds from the cultivar Metica-1 considered to be susceptible to blast. Ten days after emergence, each pot was thinned to two plants. Soil in each pot was fertilized before sowing with $1.63 \mathrm{~g}$ of calcium phosphate $/ \mathrm{kg}$ of soil and with $30 \mathrm{~mL}$ of a nutrient solution containing, in $\mathrm{g} \mathrm{L}^{-1}, 6.4 \mathrm{KCl}, 3.48 \mathrm{~K}_{2} \mathrm{SO}_{4}, 5.01 \mathrm{MgSO}_{4} .7 \mathrm{H}_{2} \mathrm{O}$, $2.03\left(\mathrm{NH}_{2}\right)_{2} \mathrm{CO}, 0.009 \mathrm{NH}_{4} \mathrm{MO}_{7} \mathrm{O}_{24} .4 \mathrm{H}_{2} \mathrm{O}, 0.054 \mathrm{H}_{3} \mathrm{BO}_{3}$, $0.222 \mathrm{ZnSO}_{4} .7 \mathrm{H}_{2} \mathrm{O}, 0.058 \mathrm{CuSO}_{4} .5 \mathrm{H}_{2} \mathrm{O}$ and $0.137 \mathrm{MnCl}_{2} \cdot 4 \mathrm{H}_{2} \mathrm{O}$. The liquid nutrient solution was applied every week. A volume of $15 \mathrm{~mL}$ of a solution containing $0.27 \mathrm{~g} \mathrm{FeSO}_{4} .7 \mathrm{H}_{2} \mathrm{O}$ and $0.37 \mathrm{~g}$ of EDTA bisodic $\mathrm{L}^{-1}$ was also applied after seedlings emergence and repeated when the plants were 30 days old. Plants were watered as needed.

Plants grown in pots containing Si-deficient typical Acrustox red yellow latosol were subjected to the following treatments: (1) calcium carbonate (control 1); (2) calcium silicate (control 2); (3) calcium carbonate and spray of soluble $\mathrm{Si}$ (Armurox ${ }^{\circ}$; Biolberica, Spain) $\left(5 \mathrm{~mL} \mathrm{~L}^{-1}\right) 24$ hours before inoculation with $P$. oryzae. For this treatment, leaves were not washed (3a) or washed (3b) with distilled water before the determination of foliar Si concentration; (4) calcium carbonate and spray of potassium silicate $\left(2.1 \mathrm{~g} \mathrm{~L}^{-1}\right) 24$ hours before inoculation with P. oryzae; (5) calcium carbonate and soil watered five times with soluble $\mathrm{Si}$ solution $(0.05 \mathrm{~mL}$ of Armurox ${ }^{\oplus}$ per pot) weekly and (6) calcium carbonate and spray of propiconazole $\left(1.5 \mathrm{~mL} \mathrm{~L}^{-1}\right) 24$ hours before inoculation with $P$. oryzae.

\section{Inoculation procedure}

A pathogenic isolate of $P$. oryzae, obtained from symptomatic rice plants, was used to inoculate the plants. Pieces of filter paper containing the fungus were transferred to Petri dishes with potato-dextrose-agar (PDA). After 3 days, PDA plugs containing fungal mycelia were transferred to new Petri dishes. Petri dishes were kept in a growth chamber at $25^{\circ} \mathrm{C}$ with a $12 \mathrm{~h}$ photoperiod for 10 days. A conidial suspension of $P$. oryzae $\left(1 \times 10^{4}\right.$ conidia $\left.\mathrm{mL}^{-1}\right)$ was applied as a fine mist to the adaxial leaf blades of each plant ( 35 days after seedling emergence, vegetative growth stage) until runoff using a VL Airbrush atomizer (Paasche Airbrush Co., Chicago, IL). Gelatin $\left(1 \%\right.$, wt $\left.\mathrm{v}^{-1}\right)$ was added to the sterile water to aid conidial adhesion to the leaf blades. Immediately after inoculation, plants were transferred to a mist chamber at $25 \pm 2^{\circ} \mathrm{C}$ with an initial $24 \mathrm{~h}$ dark period. After this $24 \mathrm{~h}$ period, plants were incubated using a $12 \mathrm{~h}$ photoperiod of ca. $162 \mu \mathrm{mol} \mathrm{m}^{-2} \mathrm{~s}^{-1}$ provided by cool-white fluorescent lamps. The relative humidity inside the mist chamber was approximately $95 \pm 2 \%$ throughout the experiments. Plants were kept inside the mist chamber for the duration of the experiments. 


\section{Blast assessment}

The fourth and fifty leaves from the main tiller of each plant were marked and used to evaluate the incubation period (IP), lesion size (LS), number of lesions (NL) per $\mathrm{cm}^{2}$ of leaf and blast severity. The IP (in hours) was scored by examining the marked leaves every four hours after inoculation (hai). The size $(\mathrm{mm})$ of six randomly lesions on marked leaves of each plant was measured employing an electronic digital caliper at 72 hai. Also at 72 hai, the number of lesions per $\mathrm{cm}^{2}$ of leaf area was counted at three randomized places on marked leaves per plant with a hand-held microscope $(\times 20)$. Blast severity on leaves of each plant was scored at $24,36,48,72$ and 96 hai using a scale based on the percentage of diseased leaf area (IRRI, 1996). Area under blast progress curve (AUBPC) for each leaf in each plant was computed using the trapezoidal integration of blast progress curve over time according to Shaner and Finney (1977).

\section{Plant tissue analysis and X-ray microanalysis for Si}

Leaves of plants from the six treatments listed above were removed at 100 hai. For plants sprayed with soluble Si (treatment 3), one-half of each leaf was gently washed in sterile deionized water for 10 minutes to remove any $\mathrm{Si}$ deposition on the sprayed leaf surface. The other half of each leaf was unwashed. Leaves of plants from the six treatments were analyzed for Si concentration by colorimetric analysis as described by ElliotT and SNYDER (1991) and by scanning electron microscopy coupled to an energy dispersive X-ray microanalysis mapping.

\section{Experimental design and data analysis}

The experiment was arranged in a completely randomized design with six treatments and five replications. Each experimental unity consisted of one plastic container and two rice plants. The experiment was repeated once. Data from Si concentration on leaf tissues, IP, LS, NL and AUBPC were subjected to ANOVA and means of the treatments were tested for significant differences $(\mathrm{p}=0.05)$ using Tukey's test.

\section{RESULTS}

\section{Concentration of Si on leaf tissues}

For Exp. 1, there was no significant difference among the treatments 1, 3a, 3b and 4 and also among the treatments 3a, $3 \mathrm{~b}$ and 6 for Si concentration on leaf tissues (Table 1). However, Si concentration on leaf tissues significantly increased for treatments 2 and 5 as compared to the other treatments (Table 1). For Exp. 2, there was no significant difference among the treatments $1,3 \mathrm{a}, 3 \mathrm{~b}$ and 4 and also among the treatments 1,4 and 6 (Table 1). However, Si concentration on leaf tissues significantly increased for treatments 2 and 5 as compared to the other treatments (Table 1).

\section{X-ray microanalysis of Si on leaf tissues}

A similar pattern of Si deposition was observed among the treatments based on the X-ray microanalysis (Figure 1). On the leaf surface of plants from treatments 1 (Figure 1a) and 6 (Figure 1g), Si deposition was lower compared to the other treatments. On leaves of plants from treatments 2 (Figure 1b), 3a (Figure 1c), 3b (Figure 1d) and 4 (Figure 1e), $\mathrm{Si}$ deposition was more intense in comparison to the leaves of plants from treatments 1 (Figure 1a), 5 (Figure 1f) and 6 (Figure 1g). Plates of polymerized Si were often found on the surface of leaf samples obtained from plants from treatments 3 and 4 (Figure $1 \mathrm{c}, \mathrm{d}$ ).

\section{Components of rice resistance against blast}

For Exp. 1, the IP significantly increased for the treatments 2 and 5 as compared to the treatments 1 and 4 (Table 2). There was no significant difference among the treatments 2 , 3 and 5 and also among the treatments 1, 3 and 4, but these treatments were significantly different from treatment 6 . For Exp. 2, the IP significantly increased for the treatments 2 , 5 and 6 as compared to the other treatments. There was no significant difference between the treatments 5 and $6 ; 3$ and 4; and 1 and 4 (Table 2).

Table 1. Silicon concentration $\left(\mathrm{dag}_{\mathrm{kg}}{ }^{-1}\right)$ in leaf tissues of rice plants submitted to different treatments in two different experiments

\begin{tabular}{|c|c|c|}
\hline Treatments & Exp. 1 & Exp. 2 \\
\hline 1. calcium carbonate (control 1) & $0.77 \mathrm{dc}$ & $0.62 \mathrm{bc}$ \\
\hline 2. calcium silicate (control 2) & $1.88 \mathrm{a}$ & $1.52 \mathrm{a}$ \\
\hline 3a. calcium carbonate and spray of soluble Si $\left(5 \mathrm{~mL} \mathrm{~L}^{-1}\right) 24$ hours before inoculation (non-washed leaves) & $0.75 \mathrm{dc}$ & $0.98 \mathrm{~b}$ \\
\hline 3b. calcium carbonate and spray of soluble Si $\left(5 \mathrm{~mL} \mathrm{~L}^{-1}\right) 24$ hours before inoculation (washed leaves) & $0.75 \mathrm{dc}$ & $0.93 \mathrm{~b}$ \\
\hline 4. calcium carbonate and spray of potassium silicate $\left(2.1 \mathrm{~g} \mathrm{~L}^{-1}\right) 24$ hours before inoculation & $0.70 \mathrm{~d}$ & $0.71 \mathrm{bc}$ \\
\hline 5. calcium carbonate and soil watered five times with soluble Si solution ( $0.05 \mathrm{~mL}$ Armurox per pot) weekly & $1.44 \mathrm{~b}$ & $1.72 \mathrm{a}$ \\
\hline 6. calcium carbonate and spray of propiconazole $\left(1.5 \mathrm{~mL} \mathrm{~L}^{-1}\right) 24$ hours before inoculation & $0.31 \mathrm{c}$ & $0.29 c$ \\
\hline Coefficient of variation (\%) & 6.67 & 5.55 \\
\hline
\end{tabular}

Means followed by the same letter, for each experiment, are not significantly different $(\mathrm{p}=0.05)$ according to Tukey's test 

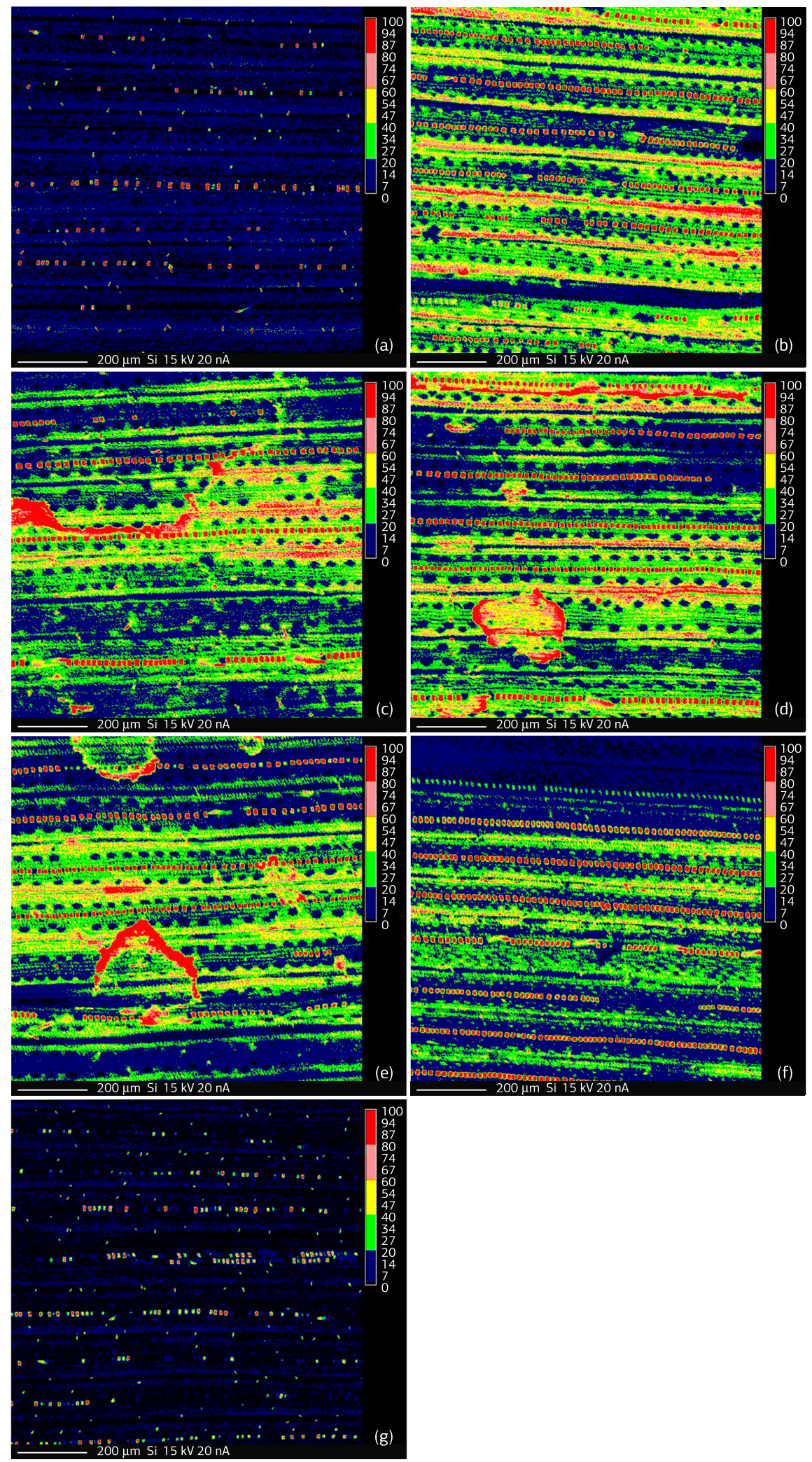

Figure 1. Silicon deposition, as determined by X-ray microanalysis, on leaves of rice plants growing in pots containing Si-deficient typical Acrustox red yellow latosol and subjected to the following treatments: calcium carbonate (a); calcium silicate (b); calcium carbonate and spray of soluble silicon 24 hours before inoculation with Pyricularia oryzae (non-washed leaves) (c); calcium carbonate and spray of soluble silicon 24 hours before inoculation with $P$. oryzae (washed leaves) (d); calcium carbonate and spray of potassium silicate 24 hours before inoculation with $P$. oryzae (e); calcium carbonate and soil watered five times with soluble silicon solution (f) and calcium carbonate and spray of propiconazole 24 hours before inoculation with $P$. oryzae $(\mathrm{g})$. Red colour indicates the highest Si deposition and black represents absence of its deposition. 
Table 2. Incubation period (IP), lesion size (LS), number of lesions (NL) and area under blast progress curve (AUBPC) evaluated in rice plants submitted to different treatments in two different experiments

\begin{tabular}{|c|c|c|c|c|c|c|c|c|}
\hline \multirow{3}{*}{ Treatments } & \multicolumn{8}{|c|}{ Components of resistance } \\
\hline & \multicolumn{2}{|c|}{$\begin{array}{c}\text { IP } \\
\text { (hours) }\end{array}$} & \multicolumn{2}{|c|}{$\begin{array}{l}\text { LS } \\
(\mathrm{mm})\end{array}$} & \multicolumn{2}{|c|}{$\begin{array}{c}\mathrm{NL} \\
\left(\mathrm{cm}^{2} \text { of leaf }\right)\end{array}$} & \multicolumn{2}{|c|}{ AUBPC } \\
\hline & Exp. 1 & Exp. 2 & Exp. 1 & Exp. 2 & Exp. 1 & Exp. 2 & Exp. 1 & Exp. 2 \\
\hline 6 & $50.8 \mathrm{a}$ & $55.6 \mathrm{a}$ & $0.18 \mathrm{~d}$ & $0.16 \mathrm{c}$ & $3.60 \mathrm{~d}$ & $3.45 \mathrm{e}$ & $40.4 \mathrm{~d}$ & $19.2 \mathrm{e}$ \\
\hline 5 & $44.6 \mathrm{~b}$ & $52.5 \mathrm{a}$ & $0.33 c$ & $0.28 \mathrm{c}$ & $9.37 \mathrm{c}$ & $6.60 \mathrm{~cd}$ & $78.6 \mathrm{~d}$ & $149.4 \mathrm{~cd}$ \\
\hline 2 & $44.4 \mathrm{~b}$ & $46.5 b$ & $0.29 c$ & $0.31 \mathrm{c}$ & $10.20 \mathrm{c}$ & $8.25 \mathrm{~cd}$ & $78.7 \mathrm{~d}$ & $167.4 \mathrm{~cd}$ \\
\hline 3 & $42.4 \mathrm{bc}$ & $41.4 c$ & $0.57 b$ & $0.63 b$ & $15.46 \mathrm{~b}$ & $14.70 \mathrm{bc}$ & $132.7 \mathrm{c}$ & $388.3 \mathrm{bc}$ \\
\hline 4 & $38.6 \mathrm{c}$ & $39.6 \mathrm{~cd}$ & $0.58 \mathrm{~b}$ & $0.65 b$ & $17.68 \mathrm{~b}$ & 19.75 b & $185.4 b$ & $550.6 \mathrm{ab}$ \\
\hline 1 & $34.0 \mathrm{c}$ & $35.8 \mathrm{~d}$ & $1.35 \mathrm{a}$ & $1.28 \mathrm{a}$ & $26.90 a$ & $22.90 \mathrm{a}$ & $1609.6 \mathrm{a}$ & $821.0 \mathrm{a}$ \\
\hline C.V. $(\%)$ & 11.4 & 13.5 & 15.80 & 10.50 & 12.50 & 13.80 & 22.8 & 19.7 \\
\hline
\end{tabular}

C.V. $=$ coefficient of variation. Treatments described in Table 1

For Exp. 1, the LS significantly decreased for treatments 2, 3,4 and 5 as compared to the treatments 1 and 6 (Table 2). There was no significant difference between the treatments 2 and 5 and also between the treatments 3 and 4. For Exp. 2, the LS significantly decreased for the treatments 2, 5 and 6 and also for the treatments 3 and 4 as compared to treatment 1 . There was no significant difference among the treatments 2 , 5 and 6 and also between the treatments 3 and 4 (Table 2).

For Exps. 1 and 2, the NL significantly decreased for the treatments 2, 3, 4 and 5 as compared to the treatments 1 and 6 (Table 2). For Exp. 1, there was no significant difference between the treatments 2 and 5 and also between the treatments 3 and 4. For Exp. 2, there was no significant difference among the treatments 2, 3, and 5 and also between the treatments 3 and 4 (Table 2).

For Exp. 1, the AUBPC significantly decreased for the treatments 2, 5 and 6 as compared to the treatments 1,3 and 4 (Table 2). There was no significant difference among the treatments 2, 5 and 6 . There was significant difference among the treatments 1, 3 and 4. For Exp. 2, there was no significant difference between the treatments 1 and 4; 3 and 4 and among the treatments 2, 3 and 5. However, the treatments 1,3 , 4 were significantly different from the treatment 6 (Table 1).

\section{DISCUSSION}

In the present study, the impact of $\mathrm{Si}$ in decreasing the IP, LS, NL and AUBPC was best achieved when this element was uptaked by the roots, which resulted in high $\mathrm{Si}$ concentration on leaf tissues. The spray of soluble Si or potassium silicate provided some blast control; however, this cannot be exclusively attributed to Si deposition on the adaxial leaf epidermis because they did not increase $\mathrm{Si}$ concentration in the leaf tissues, regardless if the leaves were washed or not before chemical analysis. It was demonstrated by X-ray microanalysis that $S i$ deposition was very similar on the leaf epidermis of plants sprayed with soluble $\mathrm{Si}$, watered with soluble Si or growing in soil amended with calcium silicate contributing, therefore, to reduce the blast symptoms.
It has been demonstrated that $\mathrm{Si}$ deposition seems to be more efficient in enhancing rice resistance against fungal infection when this element is taken up by roots (Datnoff et al., 2007). The number of lesions developing on leaf blades and sheaths of rice plants caused by the foliar pathogens P. oryzae and Rhizoctonia solani, respectively, was greatly reduced upon soil amendment with calcium silicate (Rodrigues et al., 2001; Seebold et al., 2001). Spray of potassium silicate aiming to achieve high Si concentration in rice leaf tissues was not as efficient as the soil amendment with calcium silicate. Bowen et al. (1992) reported that the thick potassium silicate deposits that coated a significant portion of the grape leaf cuticle prevented the penetration by germinating ascospores of Uncinula necator. Fungal development was more extensive in the areas of the leaf surface that had not been coated. Menzies et al. (1992) also showed that foliar applications of potassium silicate to cucumber, muskmelon and zucchini squash reduced the number of colonies of Podosphaeria xanthii and, as a consequence, decreased powdery mildew severity.

KIM et al. (2002) determined the Si accumulation in rice leaf tissues and its possible contribution to blast resistance using the $\mathrm{X}$-ray microanalysis technique associated with scanning electron microscopy. According to the authors, $\mathrm{Si}$ was deposited in the outer regions of the cell walls of epidermal cells and was associated with a possible cellular mechanism of enhanced rice resistance to $P$. oryzae infection. Although the mechanical barriers resulting from $\mathrm{Si}$ polymerization in plant tissues reduce the rice blast symptoms, Rodrigues et al. (2003) provided cytological evidences that Si-mediated resistance to $P$. oryzae in rice correlated with specific leaf cell reaction. The extent of fungal colonization was markedly reduced in plants supplied with $\mathrm{Si}$, unlike; in plants non-supplied with $\mathrm{Si}, P$. oryzae grew actively and colonized all leaf tissues. ITO and HaYASHI (1931) studied the puncture resistance of epidermal cells to a needle tip from beneath a torsion balance using leaves collected from rice plants grown under different Si rates. The puncture resistance was not explained solely by the leaf epidermis silicification; rather, it was attributed mainly to the nature of the protoplasm of epidermal cells. SEEBold et al. (2001) quantified the effects of $\mathrm{Si}$ on several components of resistance 
to blast. They provided clear evidence that by increasing $\mathrm{Si}$ rates, the incubation period was lengthened and the number of sporulating lesions, lesion size, rate of lesion expansion and the number of conidia per lesion on leaves of rice plants were markedly reduced. In another study, it was reported that rice cultivars resistant to blast had lower lesion numbers and more silicified epidermal cells than the susceptible ones (Kawamura et al., 1948).

\section{CONCLUSION}

Blast symptoms were reduced on leaves of rice plants that were root or foliar supplied with soluble $\mathrm{Si}$, indicating the importance of this element to increase resistance against P. oryzae infection.

\section{REFERENCES}

BÉLANGER, R.R.; BOWEN, P.A.; EHRET, D.L.; MENZIES, J.G. Soluble silicon: its role in crop and disease management of greenhouse crops. Plant Disease, v.79, p.329-336, 1995. http://dx.doi. org/10.1094/PD-79-0329

BOWEN, P.; MENZIES, J.; EHRET, D. Soluble silicon sprays inhibit powdery mildew development on grape leaves. Journal of the American Society for Horticultural Science, v.117, p.906-912, 1992.

DATNOFF, L.E.; DEREN, C.W.; SNYDER, G.H. Silicon fertilization for disease management of rice in Florida. Crop Protection, v.16, p.525-531, 1997. http://dx.doi.org/10.1016/S0261-2194(97)00033-1

DATNOFF, L.E.; RODRIGUES, F.A.; SEEBOLD, K.W. Silicon and Plant Nutrition. In: DATNOFF, L.E.; ELMER, W.H.; HUBER D.M. (Eds.). Mineral nutrition and plant disease. Saint Paul: APS Press, 2007. p.233-246.

ELLIOTT, C.L.; SNYDER, G.H. Autoclave-induced digestion for the colorimetric determination of silicon in rice straw. Journal of Agricultural and Food Chemistry, v.39, p.1118-1119, 1991. http:// dx.doi.org/10.1021/jf00006a024

GUÉVEL, M.H.; MENZIES, J.G.; BÉLANGER, R.R. Effect of root and foliar applications of soluble silicon on powdery mildew control and growth of wheat plants. European Journal of Plant Pathology, v.119, p.429-436, 2007. http://dx.doi.org/10.1007/s10658-007-9181-1

INTERNATIONAL RICE RESEARCH INSTITUTE - IRRI. Standard Evaluation System for Rice. Manila: The Philippines, 1996.

ITO, S.; HAYASHI, H. On the relation of silica supply to rice blast. Journal of Sapporo Society of Agricultural Science, v.103, p.460461, 1931.

KAWAMURA, E.; ONO, K. Study on the relation between the preinfection behavior of rice blast fungus, Pyricularia oryzae, and water droplets on rice plant leaves. Journal of the National Agricultural Experiment Station, v.4, p.1-12, 1948.
KIM, S. G.; KIM, K.W.; PARK, E.W.; CHOI, D. Silicon-induced cell wall fortification of rice leaves: A possible cellular mechanism of enhanced host resistance to blast. Phytopathology, v.92, p.1095-1103, 2002. PMid:18944220. http://dx.doi.org/10.1094/PHYTO.2002.92.10.1095

LIANG, Y.C.; SUN, W.C.; ROMHELD, V. Effects of foliar- and root-applied silicon on the enhancement of induced resistance to powdery mildew in Cucumis sativus. Plant Pathology, v.54, p.678685, 2005. http://dx.doi.org/10.1111/j.1365-3059.2005.01246.x

MENZIES, J.; BOWEN, P.; EHRET, D.; GLASS, A.D.M. Foliar applications of potassium silicate reduce severity of powdery mildew on cucumber, muskmelon, and zucchini squash. Journal of the American Society for Horticultural Science, v.112, p.902-905, 1992.

OU, S.H. Rice diseases. 2.ed. Commonw. Agric. Bur., Kew, 1985.

RODRIGUES, F.A.; BENHAMOU, N.; DATNOFF, L.E.; JONES, J.B.; BÉLANGER, R.R. Ultrastructural and cytochemical aspects of silicon-mediated rice blast resistance. Phytopathology, v.93, p.535-546, 2003. PMid:18942975. http://dx.doi.org/10.1094/ PHYTO.2003.93.5.535

RODRIGUES, F.A.; DATNOFF, L.E.; KORNDORFER, G.H.; SEEBOLD, K.W.; RUSH, M.C. Effect of silicon and host resistance on sheath blight development in rice. Plant Disease, v.85, p.827832, 2001. http://dx.doi.org/10.1094/PDIS.2001.85.8.827

RODRIGUES, F.A.; JURICK, W.M.; DATNOFF, L.E.; JONES, J.B.; ROLLINS, J.A. Silicon influences cytological and molecular events in compatible and incompatible rice-Magnaporthe oryzae interactions. Physiological and Molecular Plant Pathology, v.66, p.144-159, 2005. http://dx.doi.org/10.1016/j.pmpp.2005.06.002

RODRIGUES, F.A.; McNALLY, D.J.; DATNOFF, L.E.; JONES, J.B.; LABBE, C.; BENHAMOU, N. Silicon enhances the accumulation of diterpenoid phytoalexins in rice: A potential mechanism for blast resistance. Phytopathology, v.94, p.177-183, 2004. PMid:18943541. http://dx.doi.org/10.1094/PHYTO.2004.94.2.177

SAVANT, N.K.; SNYDER, G.H.; DATNOFF, L.E. Silicon management and sustainable rice production. In: SPARKS, D.L. (Ed.). Advances in Agronomy. Academic Press, 1997. p.151-199.

SEEBOLD, K.W.; KUCHAREK, T.A.; DATNOFF, L.E.; CORREAVICTORIA, F.J.; MARCHETTI, M.A. The influence of silicon on components of resistance to blast in susceptible, partially resistant, and resistant cultivars of rice. Phytopathology, v.91, p.63-69, 2001. PMid:18944279. http://dx.doi.org/10.1094/PHYTO.2001.91.1.63

SEEBOLD, K.W.; DATNOFF, L.E.; CORREA-VICTORIA, F.J.; KUCHAREK, T.A.; SNYDER, G.H. Effect of silicon rate and host resistance on blast, scald, and yield of upland rice. Plant Disease, v.84, p.871-876, 2000. http://dx.doi.org/10.1094/PDIS.2000.84.8.871

SHANER, G.; FINNEY, R.E. The effect of nitrogen fertilization on the expression of slow-mildewing resistance in Knox wheat. Phytopathology, v.67, p.1051-1056, 1977. http://dx.doi.org/10.1094/Phyto-67-1051

SKAMNIOTI, P.; GURR, S.J. Against the grain: safeguarding rice from rice blast disease. Trends in Biotechnology, v.27, p.141-150, 2009. PMid:19187990. http://dx.doi.org/10.1016/j.tibtech.2008.12.002

YOSHIDA, S.S.; OHNISHI, Y.; KITAGISHI, K. Histochemistry of silicon in rice plant. (III) The presence of cuticle-silica double layer in the epidermal tissue. Japanese Journal of Soil Science and Plant Nutrition, v.8, p.107-113, 1962. 